\title{
The formation of nurses in residency programs in public and private intensive care units
}

\author{
A formação de enfermeiros residentes em \\ UTI em instituição pública e privada \\ La formación de enfermeros residentes \\ en UCl en Instituciones públicas y privadas
}

\author{
lasmim Lima Aguiara \\ Lívia Magalhães Costa Castrob \\ Anna Gabriella Carvalho Rangelc \\ Larissa Chaves Pedreirad \\ Norma Carapiá Fagundes ${ }^{\mathrm{e}}$
}

\begin{abstract}
This qualitative study aimed to acknowledge the importance of practice in public and private institutions in the training of nurses in residency programs. Data were collected at two hospitals between February and March 2013, through interviews. From their analysis the following categories emerged: experience of graduate nurses in residency programs in ICUs of public and private institutions and potential for learning in public and private institutions regarding the training of nurses. Differences were detected in the work process and in the profile of patients between the public and private fields, and dissociation between caring and management functions carried out by residents was demonstrated. It was concluded that the development of practices in public and private institutions provides different and complementary experiences which prepare residents for management and care activities, improve management and technical assistance skills, encourages the exercise of in-service education and, by means of surveys, the search for solutions to problems that emerge from daily work.
\end{abstract}

Descriptors: Internship and residency. Nursing. Intensive care units. Nursing education.

\section{RESUMO}

Estudo qualitativo que objetivou conhecer a importância da prática em instituições públicas e privadas na formação de enfermeiros residentes. Os dados foram coletados em dois hospitais entre fevereiro e março de 2013, por meio de entrevistas. Da análise temática emergiram as categorias: vivência nas UTIs de instituições públicas e privadas a partir de enfermeiros residentes e potencial de aprendizado em instituições públicas e privadas na formação de enfermeiros intensivistas. Apontam-se diferenças no processo de trabalho e no perfil de pacientes entre os campos público e privado e indica-se dissociação entre as funções assistencial e gerencial pelos residentes. Concluiu-se que o desenvolvimento de práticas em instituições públicas e privadas oportuniza vivências distintas e complementares que preparam os residentes para atuação gerencial e assistencial, aperfeiçoam competências gerenciais e técnico-assistenciais, estimulam o exercício da educação em serviço e a busca, na pesquisa, de soluções para problemas que emergem do trabalho.

Descritores: Internato e residência. Enfermagem. Unidades de terapia intensiva. Educação em enfermagem.

\section{RESUMEN}

Estudio cualitativo que tuvo como objetivo conocer la importancia de la práctica en instituciones públicas y privadas en la formación de enfermeros residentes. Los datos fueron recolectados en dos hospitales entre febrero y marzo de 2013, por medio de entrevistas. Del análisis temático surgieron las categorías: vivencia en las UCIs de instituciones públicas y privadas a partir de enfermeros residentes; potencial de aprendizaje en instituciones públicas y privadas en la formación de enfermeros intensivistas. Se observan diferencias en el proceso de trabajo y en el perfil de pacientes entre los campos público e privado y se observa disociación entre las funciones asistencial y gerencial por los residentes. Se concluye que el desarrollo de prácticas en instituciones públicas y privadas proporciona vivencias distintas y complementarias que prepara a los residentes para la actuación gerencial y asistencial, perfecciona competencias gerenciales y técnico-asistenciales, estimula el ejercicio de la educación en servicio y la búsqueda, a través de la investigación, de soluciones para problemas que surgen del trabajo.

Descriptores: Internado y residencia. Enfermería. Unidades de cuidados intensivos. Educación en enfermería.
D0l: $\quad$ http://dx.doi.org/10.1590/1983-

1447.2014.04.45907 


\section{口INTRODUCTION}

In view of the complexity of the activities developed in Intensive Care Units (ICU) it is necessary to know the perception of residents about their fields of practice. Our purpose is to understand in which way this experience impacts the professional formation of residents and establish the potential for learning offered by each field, besides proposing improvements and sharing experiences that encourage formation.

The lack of studies on practice in public and private health services during the formation of intensivist nurses provide justification for the present study to the extent that it points to opportunities for the improvement and adjustment in the organization of these practices for nursing residency programs.

Changes in the labor market in the health sector favored the growth of the private tertiary sector. Some studies report the concentration of health jobs in the private sector, indicating the need to discuss the formation of residents on their specific areas of professional activity after the programs ${ }^{(1)}$.

Professional formation impacts the way of thinking and acting of health workers and stimulates the reflection on their work processes. Thus, the healthcare model proposed by the Unified Health System (SUS) encourages investments in the training of these professionals.

The Residency program is inserted in this logic as a training model that promotes learning by experimentation based on the critical thinking about daily work-related situations, resulting in the reorganization of practices.

The Residency program appeared as a training strategy of continuing education, based on the integration between teaching and service, aiming at ensuring additional professional training by promoting greater integration of residents and their everyday practice. (2) The profile of the health worker is improved during residency, in the practical experiences, either in public or private institutions.

Therefore, the organizational and structural differences interfere with the dynamics of the work processes, and experimentation, inherent to everyday work, confers greater significance to knowledge and training required in the area of expertise.

The work in hospital, particularly in ICU, is distinguished by the complexity and diversity of work activities and processes in their continuous dynamics.

ICU care is characterized by technical, high-quality and complex care based on permanent monitoring, continuing assistance and the incorporation of technologies, which requires permanent training and improvement ${ }^{(3)}$.
Intensivist nurses should be able to combine care planning with ICU management practices, ensuring forecast, provision and control of human resources and materials and professional education for the development of collective work $^{(4)}$.

The complexity of this work process requires high technical-scientific competence for fast and assertive decision making, as well as to enable multidisciplinary care in an environment characterized by unstable and critically ill patients, diversity of processes and routines, advanced physical and technological structure and constant multidisciplinary interaction ${ }^{(4-5)}$.

This study was based on the monograph titled "Importance of practice in public and private institutions in the formation of resident nurses ${ }^{\prime \prime(6)}$ and guided by the concern of the authors, in coordination and mentorship roles, and participating in a nursing residency program in intensive care with the following question: What is the importance of practice in public and private institutions on the formation of nurses in residency programs in intensive care? And the purpose of this study is to gain knowledge on the importance of practice in public and private institutions on the formation of graduate nurses in residency programs.

\section{METHOD}

This is a qualitative study conducted with graduate nurses in Nursing Residency Programs who are performing their duties in two ICUs of two hospitals in Salvador: one called ICU A (public), and the other called ICU B (private), where all residents spend part of their training time.

ICU A is located in a large, public, tertiary teaching hospital that provides complex services certified by the Ministries of Health and Education. ICU B is located in a medium-sized, private hospital that provides medium to highly complex services, devoted to excellence in critical medicine.

The assessed Residency Program is 12 years old. Its initial format was the one recommended by the National Commission on Multidisciplinary Research in Health. The teaching staff is composed of masters and doctors of a federal institution ${ }^{(3)}$.

In the first 10 years of the program, 148 intensivist nurses graduated, and $83.5 \%$ of de graduates were fully satisfied and $16.5 \%$ were partially satisfied regarding the importance of this formation in the development of skills for the professional market ${ }^{(3)}$.

This study counted on the participation of eight graduate nurses in the second year of the residency program, the inclusion criterion being at least three months of experience in each field of practice. 
Interviews were discontinued after data saturation. Data collection was performed between the months of February and March 2013, using guided semi-structured interviews on the themes: experience in ICUs in public and private institutions and resident's perception of the meaning of the experience in these institutions for their educational process.

All participants signed the Free and Informed Consent form before the interview, and the institutions that executed the program and provided the training previously authorized the research. Data analysis was based on thematic analysis, according to the following steps: pre-analysis, use of material resources and processing of the data obtained and interpreted. For the creation of the categories of analysis, the core meanings of the interviews were identified with " $R$ " to ensure their confidentiality ${ }^{(7)}$.

This study was approved by the Research Ethics Committee of the School of Nursing of Universidade Federal da Bahia, under protocol no 325.677, on July 3, 2013 (CAAE 11216213.6.0000.5531).

\section{- RESULTS AND DISCUSSION}

Regarding the respondents, 75\% were female and 25\% were male. All of them were aged 22- 29 years.

The following categories of analysis were obtained from the data collected: experience in ICUs of public and private institutions reported by nurses in residency programs; potential for learning in public and private institutions and its impact on the formation of intensivist nurses.

\section{Experience in ICUs of public and private institutions reported by nurses in residency programs}

The efficient use of resources in healthcare facilities ensures their sustainability, since the investments in the recovery and maintenance of life result in increased costs for providing health care. Thus, nurses are required to improve their skills in the management and rational use of resources, in order to ensure the financial and operational viability of their health care actions. ${ }^{(8)}$.

According to the respondents, resource management is the crucial point that distinguishes the hospital setting in public and private institutions: they have different ways to control the use of inputs in the organization of work processes. The following statements illustrate this:

The public institution is a very rich field. You are not involved with red tape and learn more about nursing care.
In the private sector, in turn, you'll learn how to optimize material resources (administrative area), to prevent losses, because everything must be accounted for, everything must be recorded. (R3).

The experience in a private institution is more complicated. The burden of red tape is much higher [...] And you are much more demanded in the management and caring functions, which makes things difficult for you. (R4).

Public and private healthcare institutions differ regarding aspects that involve profit, technological innovation, work processes and the care provided ${ }^{(9)}$.

Disparities between these two types of hospitals emerged from the statements because of the different management practices in these facilities. A study on costs in hospital management showed that the efficiency or inefficiency of control actions and the more or less positive appraisal of management tools resulted from the need for efficiency and the political, legal, social and cultural policies adopted $^{(10)}$.

The testimonies demonstrate that the activities related to the use of inputs are not a priority in ICU A. However, the field is considered rich because it allows exploring care-related technical and operational skills.

A study conducted with health professionals working in ICUs of public and private facilities corroborated the statements of R3 and R, by showing that some professionals felt dissatisfied with activities perceived as bureaucratic ${ }^{(11)}$.

Thus, we can infer that nurses in residency programs in ICU feel greater professional satisfaction in providing direct care to patients, which makes it difficult to see control activities as inherent to the work process of nurses and their importance in the training process.

In the following excerpts, the respondents indicate that the management model adopted is associated to greater freedom for providing nursing care.

Public institution, [...] residents are less demanded regarding audits. They are more able to deliver a good job [...]. (R2)

The public institution is a very rich field, and nurses do not have to be so concerned with material resources [...] residents are more participative [...] are more able to provide care to patients [...]. (R3)

The statements indicate the lesser importance attached by residents to the management of care in ICU $A$ and their poor understanding of the nature of the nursing job, which is always a caring/management practice. 
Other studies also showed nurses' perception of the split between the caring and management dimensions, which would result from the greater appreciation of technical procedures and because they associated management exclusively to cost control. This division does not favor the implementation of care management, which imposes a link between managing and caring ${ }^{(12)}$.

The residents associated control to bureaucratic tools and believed that these tools kept them away from caring practices and from what they perceived as the function of an intensivist nurse. In contrast, a study conducted in 2008, in Paraná, affirmed the association between management and caring and demonstrated that "[...] in the nurse's viewpoint, managing ICUs means providing care [...] managing nursing care and managing the healthcare team"(13).

The involvement of nurses in resource management is explained by the fact that ICUs require a substantial and diversified supply of material, human and technological resources to promote the rational and ethical use of public resources. So, the development of management skills should be contemplated in the training programs and enhanced as an activity inherent to intensivist nurses and to the social role of healthcare workers ${ }^{(8)}$.

According to this model, the nursing professional manages and coordinates the activities, being also actively involved in cost control and reduction. The professional is encouraged to monitor the use of material resources and drugs through quantification tied to justification for use ${ }^{(14)}$, especially in private institutions where health operators and funding sources associate this monitoring practice to the reimbursement for the services rendered.

Even when they describe control as an effective management tool, the statements of the residents are contradictory:

In the private institutions there is another aspect, that is, we see things as they really should be .. a fully structured intensive care unit, with all types of bandages available, all the required technology. Lack of materials is very rare here. However, you have to face the paperwork [...] ask for material resources all the time [...] it is a very technicist job. I believe that this impairs the critical thinking of residents. (R2)

Although the respondent reports that the organization of health services in the private institution favors the work process of the caring practice, making it possible to experience the ideal practice, because "things are as they should be", he/she criticizes the management model, and affirms that the controls implemented cause inefficiency and that the administrative procedures related to such controls have a technicist character. This scenario does not provide evidence of the recognition by the resident of the importance of the so-called management activities.

Protocols, checklist or guidelines that establish rules to reduce inacceptable changes in practice were adopted in the institutions as tools to promote safe and high-quality health care, a strategy to facilitate and control multidisciplinary work processes. However, the implementation of this routine can be regarded as another bureaucratic activity by residents ${ }^{(15)}$.

According to some respondents, the activities developed in the ICU of the public hospital favor greater autonomy for the exercise of management practices by the nurse, while in the private hospital the strategies adopted for ensuring control further restrict the residents' activities.

The testimonies indicate that the residents are unfamiliar with the management functions of intensivist nurses. They also demonstrate that the residents do not understand the importance of these activities for the implementation of comprehensive and multidisciplinary care in the ICU. When they enter the residency program, many newly graduated nurses do not know or do not value the role of manager of the unit and of the nursing team played by the intensivist nurse, and tend to value only the health care practice, at bedside, and the discussions of clinical cases.

This scenario stimulates discussions on possible gaps in nursing education. Although nurses are responsible for the coordination of work processes in health services, their formation emphasizes the development of technical skills to the detriment of communication skills, and sometimes fails to provide opportunities for experiences that reflect the everyday management of conflicts and resources essential to the management of health are in intensive care ${ }^{(16)}$.

A study reports that emphasis on the care practice and the possible ignorance of the duties of the profession may contribute to minimize the importance of the work of nurses ${ }^{(17)}$. Such evidence highlights the need to implement, in the residency program curricula, approaches that promote reflection on the work process of nurses and on the care planning by nurses in the residency program.

Therefore, interrelating care and management aspects, during the discussion of patient issues, and combining these contents in theoretical classes are measures that could be taken to stress the importance of the referred aspects in the provision of high-quality health care.

\section{Potential for learning in public and private institutions in the training of intensivist nurses}

Besides the management model adopted in each practice field, the residents reported that the profile of patients 
as a factor that enhances different learning activities in each one of the fields. The experiences of nurses in their interactions with patients, which require the planning and implementation of different care actions, encourage the acquisition of new knowledge and stimulate different reflections that are complementary to the professional formation.

In the public institution, I had the opportunity to work with much more complex patients, who demanded greater attention and more sophisticated care... the experience was very rich, since I learned about pathologies of which I had not heard before in the private institution. (R1)

I experienced several different cases in the public institution that greatly enriched my knowledge... there are many more cases, and I learned a lot.(R7)

In the private institution we deal with more chronic patients, with long hospital stay, of different ages, older patients [...]. (R8)

The practice field of the residency program in ICU A concerns the provision of highly complex services, which explains the greater number of critical patients in the unit. This scenario demands curative and restorative health care practice, where technical skills are valued, as exposed by one resident who reported the greater complexity of this unit.

The chronicity and the long hospital stay of patients reported by R1 and R8 were also identified in a study that addresses the clinical characteristics and the severity of patients admitted to public and private ICUs. The study indicated that the patients admitted to ICUs in private institutions were old, with higher prevalence of comorbiditie and chronic diseases. Although in both institutions the patients had a similar risk of death upon admission, hospital stay and mortality rate were significantly higher in the public institutions ${ }^{(18)}$.

In the private institution, I have experience with not so critical patients, who have few complications, most of them chronic, with neurological syndromes. (R1)

In the private institution we deal with more chronic patients, with long hospital stay, of different ages, older patients [...]. (R8)

The care to critical patients supposes the development of skills to manage and provide more complex services, manage resources, decision making, leadership and communication (interpersonal relations) to coordinate the work processes. ${ }^{(4)}$. The statements of the residents portray the technical improvement of care administered to chronic and acute patients, resulting in gains in learning and in the development of skills to deal with the two profiles of patients in the ICUs.

This valuation is common among intensivist nurses, who, according to their professional profile, include the following motivating factors in the workplace: emergency care, diversity of situations, constant changes in routines and work processes due to the instability and severity of critically ill patients and with risk of death ${ }^{(19)}$.

It is known that the scenario for the funding of healthcare actions in Brazil has led to a significant growth, in the past decades, of the private sector, which is evident in the prevalence of ICU beds in this segment. ${ }^{(20)}$. Thus, it is important to maintain the two types of practice fields in the formation of intensivist nurses, in order to prepare these workers for the different sectors where they can be employed after graduation.

We should always compare both institutions, because when we enter the residency program we don't know where will be working. Thus, it is important to have practice in private and public facilities, to be prepared for the labor market and for the things that we'll face when we finish the residency program. (R4)

Concerning training, the possibility of acting in different fields favors the development of a wider spectrum of learning activities, which is facilitated by the construction of environments for reflection on the practice, as seen in the report of R4. The confrontation between the world views of these two fields contributes to the formation of new knowledge, expertise and ideas that will help solve real problems, as well as to the development of the current requirements to be met in Brazil by intensivist nurses.

By facing different everyday situations, the residents acknowledged the importance of the residency program in the referred institutions to complement their training needs. The reflections on the differences in work processes indicate that the model adopted by this Program tends to promote the participation of graduates in the transformation of the reality of everyday practices in ICUs.

The Program was very important for me because the two fields are completely different. (R6).

Because of the time taken, the greater demand concerning administrative issues in private facilities than in public fa- 
cilities, the level of complexity of the patients, experience in both fields is essential. (R5)

In this context, the experience of everyday issues stimulates critical thinking and supports the autonomous professional practice where these experiences and reflections can lead to changes, based on decisions consistent with health care needs. ${ }^{(17)}$.

\section{—FINAL CONSIDERATIONS}

The study aimed to gain knowledge on the importance of practice in public and private institutions in the training of graduate nurses in residency programs in intensive care. The residents are in favor of the development of practice-based learning in the two studied fields, because the residents can learn and develop skills based on the peculiarities of each institution.

In the private environment, the resident identifies the opportunity to improve administrative skills. In the public environment, the resident can learn more about technical and assistance skills related to direct patient care.

The statements also reflect the dissociation between planning and operation of care and the maximization of the importance of direct care actions, to the detriment of those related to care management. Although experience in the two fields provides teaching activities related to service and research, these were not reported by the residents.

The training provided by this program may favor the practice of nurses under the Unified Health System (SUS), by making them able to plan and implement care to critical patients while maintaining effective control of care and mastering the management of the work process of a critical care unit.

The nursing curricula should make explicit the importance of spaces to promote discussion and reflection on the experiences of health professionals in public and private institutions, since they create valuable opportunities to transform, through research, ICU care practices and to provide the residents with the skills required to perform a technical-management activity and coordinate teaching and service.

It is concluded that the development of practices in public and private institutions prepares residents for the labor market, by offering them different experiences that complement their learning under the management models adopted in each institution.

One limitation of this study was the small sample size (only one group of professionals) and its restriction to one geographical area. However, we believe that the issues raised here can have impact on other fields.

\section{Q REFERENCES}

1. Departamento Intersindical de Estatística e Estudos Socioeconômicos (BR). 0 trabalho na Saúde- 1998-2008. Bol. Trab. Saúde [Internet]. 2009 dez[citado 2014 fev 16];1(1):1 Disponível em: http://www.dieese.org.br/estudosetorial/ 2009/2009pedsetoriaissaude.pdf.

2. Presidência da República (BR). Lei n. 11.129, de 30 de junho de 2005. Institui o Programa Nacional de Inclusão de Jovens - ProJovem; cria o Conselho Nacional da Juventude (CNJ) e a Secretaria Nacional da Juventude; altera as Leis n. 10.683, de 28 de maio de 2003, e 10.429, de 24 de abril de 2002; e dá outras providências. Diário Oficial [da] República Federativa do Brasil. 2005 jul 01;147(125Seção 1):1-2.

3. Castro LMC. Estudo de egressos de uma residência de enfermagem em terapia intensiva da Bahia [dissertação]. Salvador: Universidade Federal da Bahia;2014. 132 f.

4. Camelo SHH. Professional competences of nurse to work in intensive care units: an integrative review. Rev Latino-Am Enferm [Internet]. 2012 fev [cited 2014 mar 5];20(1):192-200. Disponível em: http://www.scielo.br/scielo. php?script=sci_arttext\&pid=S0104-11692012000100025\&lng=en

5. Adler-Milstein J, NealK, Howell MD. Residents' and nurses' perceptions of team function in the medical intensive care unit. J Crit Care. 2011;26(1):104.e7-15.

6. lasmim LA. Importância da prática em instituições publica e privada na formação de enfermeiras residentes [monografia de especialização]. Salvador: Universidade Federal da Bahia; Salvador;2013. $38 \mathrm{f}$.

7. Minayo MCS. 0 desafio do conhecimento: pesquisa qualitativa em saúde. 12. ed. São Paulo: Hucitec; 2010.

8. Castilho V, Gonçalves VLM. Gerenciamento de recursos materiais. In: Kurcgant $P$, organizador. Gerenciamento em enfermagem. São Paulo: Guanabara Koogan; 2012. p.155-67.

9. Martins M, Blais R, Leite IC. Mortalidade hospitalar e tempo de permanência: comparação entre hospitais públicos e privados na região de Ribeirão Preto, São Paulo, Brasil. Cad Saúde Pública [Internet]. 2004 [citado 2014 fev 15];20(suppl.2):S268-82. Disponível em: http://www.scielo.br/scielo. php? script=sci_arttext\&pid=S0102-311X2004000800021\&lng=en\&nrm=i so. ISSN 0102-311X.

10. Leite J, Rodrigues L. A teoria institucional e o costing na contabilidade de gestão hospitalar: 0 caso da gestão central dos hospitais EPE portugueses. In: Anais do $6^{\circ}$ Congresso Iberoamericano de Administração Empresarial e Contabilidade e $4^{\circ}$ Congresso Iberoamericano de Contabilidade de Gestão; 2010 Jun 7-9; Valencia, Espanha. Valencia: Universidad; 2010. p. 1-14. [citado 2014 Mar 5]. Disponível em: http://hdl.handle.net/10198/2559.

11. Baasch D, Laner AS. Os significados do trabalho em unidades de terapia intensiva de dois hospitais brasileiros. Ciênc Saúde Coletiva [Internet]. 2011[citado 2014 Fev 13];16(suppl.1):1097-105. Disponível em: http://www.scielo.br/ scielo.php?script=sci_arttext\&pid=\$141381232011000700041\&lng=en\&nr $m=i s 0$. ISSN 1413-8123.

12. Hausmann M, Peduzzi M. Articulação entre as dimensões gerencial e assistencial do processo de trabalho do enfermeiro. Texto Contexto Enferm. 2009 abr-jun;18(2):258-65.

13. Martins JT, Robazzi MLCC, Marziale MHP, Garanhani ML, Haddad MCL. Significados do gerenciamento de unidade de terapia intensiva para o enfermeiro. Rev Gaúcha Enferm. 2009 mar;30(1):113-9. 
14. Zunta RSB, Castilho V. Faturamento de procedimentos de enfermagem em uma unidade de terapia intensiva. Rev Latino-Am Enferm [Internet]. 2001 maio-jun [citado 2014 jan 25];19(3):[9 telas]. Disponível em: http://www.eerp.usp.br/ rlae.

15. Ilott I, Booth A, Rick J, Patterson M. How do nurses, midwives and health visitors contribute to protocol based care? A synthesis of the UK literature. Intern J Nurs Stud. 2010;47(6):770-80.

16. Barlem JGT, Lunardi VL, Barlem ELD, Bordignon SS, Zacarias CC, Lunardi Filho WD. Fragilidades, fortalezas e desafios na formação do enfermeiro.Esc. Anna Nery [Internet]. 2012 [citado 2014 set03];16(2):347-63. Disponível em: http:// www.scielo.br/pdf/ean/v16n2/20.pdf.

17. Avila LI, Silveira RS, Lunardi VL, Fernandes GFM, Mancia JR, Silveira JT. Implicações da visibilidade da enfermagem no exercício profissional. Rev Gaúcha Enferm
[Internet]. 2013 [citado 2009 fev 15];34(3):102-9. Disponível em: http://seer. ufrgs.br/index.php/RevistaGauchadeEnfermagem/article/view/37874/2726.

18. Nogueira LS, Sousa RMC, Padilha KG, Koike KM. Características clínicas e gravidade de pacientes internados em UTls públicas e privadas. Texto Contexto Enferm. 2012 jan-mar; 21(1):59-67.

19. Oliveira EM, Spiri WC. Personal dimension of the work process for nurses in intensive care units. Acta Paul Enferm. [Internet]. 2011 [cited 2014 Sep 04];24(4):550-5. Available from: http://www.scielo.br/scielo. php?script=sci_arttext\&pid=S0103-21002011000400016\&lng=en. http:// dx.doi.org/10.1590/S0103-21002011000400016.

20. Gadelha P, coordenador. A saúde no Brasil em 2030: diretrizes para a prospecção estratégica do sistema de saúde brasileiro. Rio de Janeiro:Fundação Oswaldo Cruz; 2012.

\section{Author's address:}

Lívia Magalhães Costa Castro

Rua Pacífico Pereira, 381/1304, Garcia

40100-170, Salvador, BA

E-mail : livimagalhaes@gmail.com
Received: 25.03 .2014

Approved: 24.10 .2014 